\title{
White Blood Cells Count: As a Pathological Diagnostic Marker for Oral Pre- Cancerous Lesions and Conditions: A Randomized Blind Trial
}

\author{
Deepak Narang ${ }^{1}$, Shamma Shishodiya ${ }^{2}$, Jaideep Sur ${ }^{3}$ and Niyaz Fatma Khan ${ }^{4}$ \\ ${ }^{1}$ Senior Resident / Senior Lecturer Faculty, College of Dental Sciences and Research, Rungta, Bhillai, Chattisgarh, India \\ ${ }^{2}$ Diplomate national Board [DNB] Gangaram Medical college and Hospital Karol bagh, New Delhi, India \\ ${ }^{3}$ Post Graduate Faculty - @MDS[Reader] - Guide to Post graduate students, College of Dental Sciences and Research, Bhillai, Chattisgarh, India \\ ${ }^{4}$ Senior Resident / Senior Lecturer Faculty, College of Dental Sciences and Research, Bhillai, Chattisgarh, India
}

*Corresponding author: Deepak Narang, Senior Resident / Senior Lecturer Faculty [MDS, ORAL MEDICINE), College of Dental Sciences and Research, Rungta, Bhillai, Chattisgarh, India, Tel: 00915942248115; E-mail: candida.531@rediffmail.com

Received date: May 06, 2013, Accepted date: Sep 19, 2014, Published date: Sep 25, 2014

Copyright: $\odot 2014$ Narang D, et al. This is an open-access article distributed under the terms of the Creative Commons Attribution License, which permits unrestricted use, distribution, and reproduction in any medium, provided the original author and source are credited.

\begin{abstract}
Background: Oral cancer is one of the most prevalent cancers in human population. Oral cancer accounts for approximately $3 \%$ of all malignancies and results in significant worldwide health problems. Many Oral Squamous cell carcinomas develop from Oral pre-cancer such as Leukoplakia, Oral sub mucus fibrosis, and Lichen Planus. The early detection of cancer is of critical importance because of survival rates markedly improve, when the oral lesion is identified at an early stage. The present study was conducted to find out if WBC count can be used as a screening marker for diagnosis of Oral pre Cancer \& compare their levels in precancerous lesions and healthy individuals.
\end{abstract}

Methodology: A prospective study was conducted which comprised of 60 samples out of which 30 were precancerous lesions and 30 were healthy controls. In both the study and control group WBC count was measured \& compared by the standard "t-test".

Results: TLC \& DLC showed no significant differences observed between control and study group except in group C (Lichen planus) vs Control in TLC \& Eosinophil count ( $p$-value $<0.01)$.Total study group vs healthy individuals in the lymphocyte count found to be statistically highly significant differences exists ( $p$-value $<0.001$ ).

Conclusion: Our study suggested that WBC count is not a reliable method as a marker for oral pre-cancerous lesions but further detailed evaluation with larger samples required to establish the significance of these markers.

Keywords: Oral pre-cancers; White blood cells; Inflammation; Lymphocytes; Eosinophils

\section{Introduction:}

Oral cancer is one of the most prevalent cancers in the human population and it accounts approximately $3 \%$ of all carcinomas and results in significant health problems worldwide. Five Percent of Oral Squamous cell carcinoma develops from Oral pre-cancers such as Leukoplakia, Oral sub mucus fibrosis, and Lichen planus etc.

Cancer is initiated in cells when there is unwanted growth of new cells without older cells die out. Deleterious habits such as tobacco smoking, hookah smoking, chewing tobacco and alcohol have been attributed significantly to the development of oral cancer.

An early detection can make all the difference in our battle against cancer. Cancer if detected at initial stages can be completely cured with modern therapy and person can live a longer healthy \& happy life. Latest discoveries in medical sciences have led to the detection of cancer even before the person is aware of the symptoms.

Several bio-markers have been discovered such as urine [1] and saliva [2] for early diagnosis of oral cancer and pre cancer.
For several cancers an association with WBC count has been reported [3] but so far no studies have been documented for precancer with WBC count. Therefore the aim of current research was to determine the changes in the level of $\mathrm{WBC}$ counts in pre-cancerous lesions and conditions and to compare the WBC counts between control and study group of pre- cancerous lesions and conditions.

\section{Material and Methods}

Chosen for evaluation were total sixty subjects, 30 healthy controls, 30 study group comprising of Osmf (no. of patients=7), leukoplakia (no. of patients=7), Lichen Planus (no. of patients=7) (Table 2)

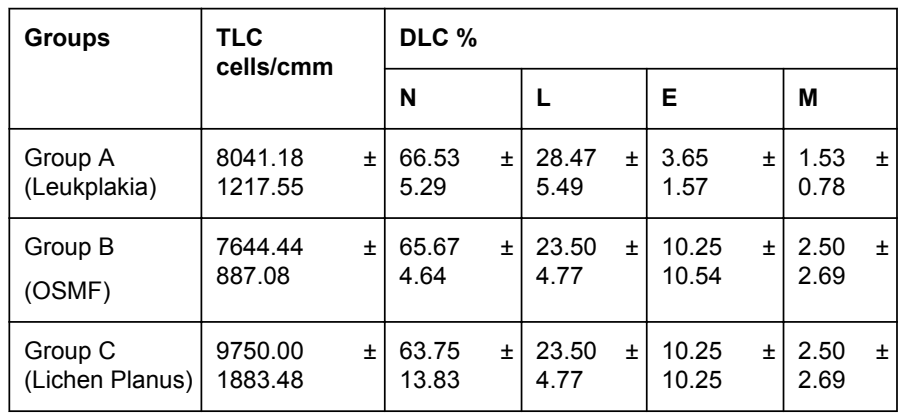


Page 2 of 3

\begin{tabular}{|c|c|c|c|c|c|}
\hline $\begin{array}{l}\text { Group D } \\
\text { (Healthy) }\end{array}$ & $\begin{array}{ll}7793.33 & \pm \\
1146.86 & \end{array}$ & $\begin{array}{ll}66.33 & \pm \\
5.24 & \end{array}$ & $\begin{array}{l}28.50 \quad \pm \\
5.06\end{array}$ & $\begin{array}{ll}3.07 & \pm \\
0.89 & \end{array}$ & $\begin{array}{l}1.80 \quad \pm \\
0.87\end{array}$ \\
\hline Total & $\begin{array}{l}8150.00 \\
1404.93\end{array}$ & $\begin{array}{l}65.90 \quad \pm \\
6.98\end{array}$ & $\begin{array}{ll}22.97 & \pm \\
5.97 & \end{array}$ & $\begin{array}{l}4.40 \\
4.69\end{array}$ & $\begin{array}{ll}1.83 & \pm \\
1.27 & \end{array}$ \\
\hline
\end{tabular}

Table 1: Mean value and standard deviation of TLC \& DLC in all groups

\section{Results}

Highly significant correlation ( $p$-value $<0.01$ ) was found in Eosinophil count and T.L.C. between group C (Lichen planus) and group D (Healthy individuals) (Table 2)

Highly significant correlation was also found between total study group $(\mathrm{A}+\mathrm{B}+\mathrm{C})$ and group $\mathrm{D}$ (Healthy individuals) in Lymphocyte count (p-value $<0.01$ ).

\begin{tabular}{|c|c|c|c|c|c|}
\hline Groups & TLC (Cell/ cumm) & DLC\% & & & \\
\hline & T- test & $\mathbf{N}$ & L & E & M \\
\hline$A$ vs $D$ & 0.696 & 0.62 & 0.019 & 1.622 & 1.060 \\
\hline$P$ Value & $>0.05$ & $>0.05$ & $>0.05$ & $>0.05$ & $>0.05$ \\
\hline$B$ vs D & 0.358 & 1.522 & 0.263 & 0.396 & 0.967 \\
\hline$P$ Value & $>0.05$ & $>0.05$ & $>0.05$ & $>0.05$ & $>0.05$ \\
\hline C vs D & 2.977 & 0.827 & 1.866 & 0.043 & 1.126 \\
\hline$P$ Value & $<0.01$ (H.S) & $>0.05$ & $>0.05$ & $<0.01$ (H.S) & $>0.05$ \\
\hline$A+B+C$ vs $D$ & 1.077 & 0.458 & 4.057 & 1.526 & 0.107 \\
\hline P Value & $>0.050 .05$ & $>0.05$ & $<0.01$ (H.S) & $>0.05(\mathrm{~S})$ & $>0.05$ \\
\hline
\end{tabular}

Table 2: Comparison of TLC and DLC in control vs Study group. $\mathrm{P}>0.05$ not significant, $\mathrm{P}<0.05$ Significant, $\mathrm{P}<0.01$ Highly significant

\section{Discussion}

This is the first ever study in this geographic region assessing the blood parameters in precancerous lesions and conditions. The purpose of this study was an attempt for a simple and cost effective method for diagnosis of oral pre cancer lesions and conditions. White blood cell count is highly variable because it is responsive to diverse acute and chronic stimuli. It is increased in infection, stress and smoking [4]. In 1863 Rudolf Virchow postulated induction hypothesis that cancer originates at site of inflammation because he observed the presence of leukocytes in neo-plastic tissue [5]. Increasing evidence suggest that inflammation may be linked to the pathogenesis of cancer. The stromal tissue of tumors has high WBC count and inflammatory cells and their cytokine production seems to co-relate with tumor severity [6].

Due to its non-specificity WBC count can predict the risk of multiple diseases including cancer. Grim et al (1985) reported that WBC count was associated with risk of cancer death. Erlinger et al (2004) postulated WBC count with cancer mortality [7]. Shankar et al (2006) also found an association between high WBC count and cancer mortality [8]. The evidence seems to be increasing that, cellular proliferation in an environment rich in, inflammatory cells, growth factors and activated stroma is associated with DNA damage that can potentiate the growth of cancer cells [9].

In our study highly significant co-relation (p-value<0.01) of Eosinophilic count and T.L.C. between group C (Lichen planus) and group D (Healthy individuals) was seen (Table 2). This could be due to unequal sample size in all study groups. Highly significant co-relation ( $\mathrm{p}$-value $<0.01$ ) of Lymphocyte count was also found between total study group $(\mathrm{A}+\mathrm{B}+\mathrm{C})$ and Healthy individuals (group D) was seen. This could be attributed that, major role of Lymphocytes in the pathogenesis of pre-cancer and cancer. Since in our study only lymphocytes count showed drastic changes.

\section{Conclusion}

We concluded that chronic inflammation is a underlying pathology might have causative factor in the progression of precancerous lesions in to cancer. Future recommendation, evaluating the study with larger samples including grades of dysplasia to establish the significance of WBC count as a diagnostic marker.

\section{References:}

1. Guo X, Xiee, Tian L, Chene Yun P, et al (2011). Metabolomics

2. Li Y, St John MA, Zhou X, Kim Y, Sinha U, et al. (2004) Salivary transcriptome diagnostics for oral cancer detection. Clin Cancer Res 10: 8442-8450.

3. Lee YJ, Lee HR, Nam CM, Hwang UK, Jee SH (2006) White blood cell count and the risk of colon cancer. Yonsei Med J 47: 646-656.

4. Jee SH, Park JY, Kim HS, Lee TY, Samet JM (2005) White blood cell count and risk for all-cause, cardiovascular, and cancer mortality in a cohort of Koreans. Am J Epidemiol 162: 1062-1069.

5. Coussens LM, Werb Z (2002) Inflammation and cancer. Nature 420: 860-867.

6. Balkwill F (2004) Cancer and the chemokine network. Nat Rev Cancer 4: 540-550.

7. Madjid M, Awan I, Willerson JT, Casscells SW (2004) Leukocyte count and coronary heart disease: implications for risk assessment. J Am Coll Cardiol 44: 1945-1956.

8. Coussens LM, Werb Z (2002) Inflammation and cancer. Nature 420: 860-867.

9. Shankar A, Mitchell P, Rochtchina E, Tan J, Wang JJ (2007) Association between circulating white blood cell count and long-term incidence of 
Citation: Narang D, Shishodiya S, Sur J, Khan NF (2014) White Blood Cells Count: As a Pathological Diagnostic Marker for Oral Pre-Cancerous Lesions and Conditions: A Randomized Blind Trial. J Carcinog Mutagen 5: 188. doi:10.4172/2157-2518.1000188

Page 3 of 3

age-related macular degeneration: the Blue Mountains Eye Study. Am J

Epidemiol 165: 375-382. 